\title{
La tertulia. Sociabilidad, comunicación y literatura en el siglo XVIII: perspectivas teóricas y ejemplos literarios (Quijano, Jovellanos, Cadalso) \\ Andreas Gelz \\ Universidad de Postdam
}

Hubo épocas, en España, en que casi toda la vida nacional se fraguaba en las tertulias. [...] Puede decirse que España entera consistía en un vasto sistema de tertulias que lanzaban sus fueros en múltiples direcciones, chocando unas con otras o confluyendo a veces a su paso torrencialmente, e imponerse como potencia única. [...] en definitiva, la sociedad entera no es más que una inmensa reunión de tertulianos.

Antonio Espina García (Las tertulias de Madrid)

La tertulia como fenómeno de sociabilidad y de comunicación es uno de los factores más importantes y, sorprendentemente, menos analizados del desarrollo cultural en la España moderna. El fenómeno, con antecedentes en el siglo XVII (entre otros la academia literaria ubicada en el ámbito privado) y raíces en las academias del Renacimiento, nace en el siglo XVIII, conoce su auge en el xIx, y se puede observar hasta por lo menos el primer tercio del siglo xx. La tertulia representa un microcosmos social que refleja nítidamente el cambio de procesos de interacción y comunicación dentro de la sociedad. Es un indicio apropiado para el análisis de cambios políticos, culturales y mentales de la sociedad española en los umbrales de la modernidad. Son lugares de tertulia en el xvIII, además de las casas particulares aristócratas y burguesas, la librería, la farmacia, desde el segundo tercio del siglo, el café, en el xIX el 
local comercial así como una cantidad de nuevos espacios públicos como teatros ampliados con un sinnúmero de salones, clubs, círculos, gabinetes de lectura, casinos y baños ${ }^{1}$. El origen de la palabra hasta hoy día queda oscuro; pero, siguiendo su utilización en el xvIII, se supone que «tertulia» proviene de la denominación de una parte del teatro del Siglo de Oro, reservada a los estratos importantes de la sociedad, y que servía no en último lugar a fines comunicativos $^{2}$. Como sinónimo de la voz tertulia, en los textos del siglo xvIII encontramos palabras como junta, asamblea, comitiva, visita, partida, chismorreo, congreso, academia, comercio, concurrencia, para no citar más que describen diferentes modelos o aspectos de una cultura oral hoy día todavía bastante desconocida.

Después de un período en el que se analizaban sobre todo formas de comunicación y de sociabilidad institucionalizadas como la prensa, el teatro, las academias, las Sociedades Económicas de Amigos del País, el comercio del libro, la censura etc. se ha llamado recientemente la atención sobre la necesidad de un análisis de la tertulia ${ }^{3}$. Si en el pasado se mencionó la tertulia fue más bien

${ }^{1}$ Cfr. para el siglo xix Marie-Claude Lecuyer, «Algunos aspectos de la sociabilidad en España hacia 1840», en: Estudios de Historia Social, 50-51 (1989), págs. 145-159. De forma general se puede afirmar que los cambios en la forma de comunicar están relacionados con los cambios en los modelos arquitectónicos o urbanistas vigentes y viceversa: recordamos solamente, en el caso de las casas particulares, el desarrollo de aposentos de comunicación semi-privados como los salones, gabinetes y comedores que sustituyen las grandes habitaciones de representación enfiladas; o en plan urbanista la sustitución de edificios y plazas polifuncionales (p. ej. la Plaza Mayor) en favor de edificios especializados y repartidos por el tejido urbano ( $c f r$. LECUYER, «Algunos aspectos de la sociabilidad»; África Martínez Medina, Espacios privados de la mujer en el siglo XVIII, Madrid, Dirección General de la Mujer, Horas, 1995; Javier Fernández Sebastián, «Los primeros cafés en España (1758-1808): nueva sociabilidad urbana y lugares públicos de afrancesamiento», en: Aymes, Jean-René (ed.), L'image de la France en Espagne pendant la seconde moitié du XVIII ${ }^{E}$ siècle, Paris. 1996, págs. 65-82).

${ }^{2}$ Cfr. Pedro Állvarez de Miranda, Palabras e ideas: el léxico de la Ilustración temprana en España (16801760), Madrid, Real Academia Española, 1992, que propone un resumen de la investigación lexicológica.

${ }^{3}$ María Dolores Tortosa Linde, La Academia del Buen Gusto de Madrid (1749-1751), Granada, Universidad, Departamento de Filología Española, 1988; LECuyer, «Algunos aspectos de la sociabilidad»; Álvarez DE Miranda, El léxico de la Ilustración temprana; íd., «Las Academias de los Novatores», en: Evangelina Rodríguez Cuadros, De las Academias a la Enciclopedia: El discurso del saber en la modernidad, Valencia, Edicions Alfons el Magnànim, IVEI/Generalität Valenciana, Diputació Provincial de Valencia, 1993, págs. 263-300; Joaquín Álvarez Barrientos, François Lopez, Inmaculada Urzaínqui, La república de las Letras en la España del Siglo xVIII, Madrid, CSIC, 1995; François Lopez, «Instituciones y círculos culturales», en: Guillermo Carnero (ed.), Siglo XVIII (1) (Historia de la Literatura Española, ed. Victor de la Concha), Madrid, Espasa-Calpe, 1995, págs. 9-16; Fernández Sebastián, «Los primeros cafés en España»; Juan A. Ríos Carratalá, «Las obras para casas particulares de Antonio Rezano Imperial», en: Josep M ${ }^{\text {a }} \mathrm{S}_{\text {ALA }} \mathrm{V}_{\text {ALLDAURA }}$ (ed.), Teatro español del siglo XVIII, Lleida, Ed. de la Universidad de Lleida, 1996, vol. 2, págs. 687-705; para el siglo xix cfr. Andrés Peláez Martín, «De lo vivo a lo pintado. La escena modelo para pintores», en: El mundo literario en la pintura del siglo XIX del museo del Prado, Madrid, Museo del Prado et.alt., 1994, págs. 67-91; Guillermo CARNERo, «Introducción a la primera mitad del siglo XIX español», en: íd. (ed.), Siglo XIX (1) (Historia de la literatura española, ed. Víctor García de la Concha), Madrid, Espasa Calpe, 1996, págs. xvII-c. Esta exigencia corresponde a una tendencia de la investigación histórica en otros paises europeos. Cfr. Daniel Roche, Les Répu- 
de forma accidental, en el marco de trabajos monográficos (un ejemplo entre otros muchos es la monografía sobre Iriarte de Cotarelo y Mori del año 1897) y/o de historia local así como en forma de breves alusiones en introducciones al siglo XVIII español ${ }^{4}$. La única monografía dedicada a la tertulia trata de un aspecto particular, de las tertulias de rebotica, desde una perspectiva de la historia médica5. En la introducción de su historia literaria del siglo xIx, publicada en el año 1996,

blicains des lettres. Gens de culture et Lumières au XVIII siècle, Paris, Fayard, 1988; Daniel Gordon, Citizens without Sovereignty: Equality and Sociability in French Thought, 1670-1789, Princeton, Princeton University Press 1994; Dena Goodman, The Republic of Letters. A Cultural History of the French Enlightenment, Ithaca and London, Cornell University Press, 1994, donde se analiza por ejemplo la cultura de salón bajo el aspecto del origen del público, del concepto de crítica así como bajo una perspectiva feminista como parte de una historia de la comunicación de las Luces. Por muy interesantes que sean estos trabajos obedecen, a menudo, desde un punto de vista metodológico, a una teleología implícita postulando una radicalización de discursos igualitarios y de procesos prerevolucionarios que no se pueden aplicar a España. En España sólo muy recientemente se ha publicado un artículo muy general sobre el café en la España del xvIII (FERNÁNDEZ SEBAstí́n, «Los primeros cafés en España»), al contrario de una investigación ya establecida desde hace mucho tiempo en los países anglo-sajones (Aytoun Elus, The Penny Universities: a history of the coffee-houses, London, Secker \& Warburg, 1956; Bryant Lillywhite, London Coffee Houses: A Reference Book of Coffee Houses of the Seventeenth, Eighteenth and Nineteenth Century, London, Allen \& Unwin 1963; Peter EarLe, The Making of the English Middle Class: Business, Society and family Life in London 1660-1730, London, Methuen, 1989; Steven Pincus, «»Coffee Politicians Does Make»: Coffee-Houses and Restoration Political Culture», en: Journal of Modern History, 67 (1995), págs. 807-834). Para el análisis de formas de sociabilidad en el siglo XIX cfr. Maurice Agulhon, Le cercle dans la France bourgeoise 1810-1848. Étude d'une mutation de sociabilité, Paris, Colin, 1977, dió un impulso metodológico importante; en España podemos citar a Jacques MauricE, «Propuestas para una historia de la sociabilidad en la España contemporánea», en: Estudios de Historia Social, 50-51 (1989), págs. 133-143 y LECUYER, «Algunos aspectos de la sociabilidad», a pesar de que estos trabajos no renuncian al criterio de una mínima institutionalización analizando los liceos, círculos y sociedades de socorro mutuo. $\mathrm{Al}$ contrario, para la cultura oral del siglo XVII español, particularmente para las academias literarias existe ya una amplia bibliografía (José SÁnchez, Academias literarias del siglo de oro español, Madrid, Gredos, 1961; Williard F. KIng, Prosa novelística y Academias literarias en el siglo XVII, Madrid, 1963 (Anejos del Boletín de la Real Academia Española, 10 [1963]); Ma Soledad Carrasco Urgorti, «Notas sobre el Vejamen de Academias en en la segunda parte del siglo XvII», en: Revista Hispánica Moderna, 31 (1965), págs. 97-111; íd., «La oralidad del vejamen de Academia», en: Edad de Oro, 7 (1988), págs. 49-57; Aurora EGIDo, «Una introducción a la poesía y a las academias literarias del siglo XvII», en: Estudios Humanísticos (Universidad de León), 1984, págs. 9-26; $i d$., «Literatura efímera: oralidad y escritura en los certámenes y academias de los siglos de oro", en: Edad de Oro, 7 (1988), págs. 69-87; Rodríguez Cuadros, De las Academias a la Enciclopedia; Dietrich Briesemeister «Akademien in Portugal und Brasilien in der Frühen Neuzeit», en: Klaus Garber, Heinz Wismann, Winfried Siebers (ed.), Europäische Sozietätsbewegung und demokratische Tradition. Die europäischen Akademien der Frühen Neuzeit zwischen Frührenaissance und Spätaufklärung, vol. I, Tübingen, Niemeyer 1996, págs. 604-622; cfr. un resumen bibliográfico en Julia BARELLA, «Bibliografía: Academias literarias», en: Edad de Oro, 7 (1988), págs. 189-195). Recientemente la investigación se ha preocupado del tránsito de la oralidad hacia la escritura, del carácter efímero de las academias, de su relación con la producción del saber y con el mundo literario de la época.

${ }^{4}$ Charles E. Kany, Life and Manners in Madrid 1750-1800, New York, AMS, 1970 [repr. de la ed. de Berkeley 1932]; Vicente Palacio Atard, «Del sarao a la tertulia», en: íd., Los españoles de la Ilustración. Madrid, Ed. Guadarrama, 1964, págs. 209-240; Werner Krauss, «Gesellschaftlichkeit und Geselligkeit im Spanien der Aufklärung», in: íd., Aufklärung III: Deutschland und Spanien (Das wissenschaftliche Werk, ed. Martin Fontius). Berlin, New York, Walter de Gruyter, 1996, págs. 346-375 y otros más.

${ }^{5}$ José Luis Urreiztieta, Las tertulias de rebotica en España. Siglos XVIII-XX, Madrid, Alonso 1985. 
Guillermo Carnero es uno de los pocos que no sólo llama la atención sobre la importancia de la tertulia para la investigación histórica, sino que enumera también ejemplos de su tratamiento literario.

\section{La tertulia objeto de la historia cultural y literaria}

Nuestro análisis se deja guiar por la siguiente hipótesis: la significación de la palabra tertulia va mas allá de la de otros tipos de sociabilidad informal (i.e. por ejemplo el salón, el café). Tres elementos constituyen el concepto tertulia: la voz significa al mismo tiempo el espacio en que tienen lugar los actos comunicativos, la totalidad de los participantes en ella y la comunicación misma. Esta polisemia es una de las características que hacen de la tertulia un elemento sumamente interesante no sólo para la investigación histórica, sino también para la historia cultural y, como veremos, literaria, pues se trata de una noción que contiene en sí misma diversos significados que la hacen utilizable en los más diversos contextos culturales (vid. infra).

La literatura desempeña un papel clave al respecto: la tertulia como lugar de interacción de autores, artistas y músicos entre ellos y con la sociedad es al mismo tiempo objeto de una representación literaria ${ }^{6}$. En algunos casos aislados podemos incluso hablar de la tertulia como de un propio subgénero literario. Bajo la forma de una tertulia imaginada, en estos textos se pone en escena o bien un discurso reflexivo-crítico sobre los más diversos asuntos (entre los cuales se encuentra también la literatura) o la narración, lectura común y discusión de una colección de pequeños textos y relatos con el fin de divertir a los oyentes. La tertulia por su naturaleza compleja (lugar, personas y comunicación) tiene un carácter marcadamente autorreflexivo acentuándose, según el contexto, uno de los tres elementos de su significado; la literatura, por las relaciones que acabamos de describir, es el medio apropiado para esta autorreflexión.

En este juego entre tertulia imaginada y representada la retórica desempeña un papel primordial; habrá que preguntar si la praxis cultural de la tertulia induce a cambios discursivos significantes, de la homogeneidad hacia la heterogeneidad, del monólogo (cfr. el discurso religioso) hacia el diálogo, de la autoridad hacia la crítica ${ }^{7}$.

\footnotetext{
${ }^{6}$ Consta su importancia para muchos autores del xvIII y entre los cuales cabe destacar Cadalso, Iriarte, Meléndez Valdés, Huerta Jovellanos, Blanco White por no citar a otros más. Hay otros autores, como el conde de Torrepalma, cuya producción se realiza casi de forma exclusiva dentro del sistema de diferentes tertulias (Nicolás Marín, Poesía y Poetas del Setecientos. Torrepalma y la Academia del Trípode, Granada, Universidad de Granada, 1971).

${ }^{7}$ Una crítica no sólo en un sentido de un juicio estético o literario sino también en un sentido político. Falta todavía un análisis de la contribución de las tertulias en los procesos de democratización en España,
} 
En la tertulia circulan manuscritos, se procede a una lectura, a una producción de textos o a la crítica de los que se presentan a los participantes en ella. La tertulia ofrece la posibilidad de observar el cambio de normas estéticas hacia una concepción más moderna de la crítica de textos. A menudo, podemos observar cómo se utilizan en este contexto conceptos tradicionales que casi imperceptiblemente van actualizándose por emplearse en un nuevo contexto. Así se habla por ejemplo del cotejo, del certamen, del vejamen ${ }^{8}$, se utiliza a veces la noción del desengaño pero en un contexto completamente diferente, atribuyéndole un nuevo significado. Junto al tópico del desengaño encontramos en este contexto imágenes mitológicas aplicadas a la literatura - Marte, como alegoría de la competición entre los escritores, el Parnaso- que se utilizan aunque cambiando a su vez paulatinamente de significado.

La tertulia es, además, un cuadro de diversas actividades culturales, de las cuales la literatura es solamente una parte, junto con la música, el teatro, el baile, la conversación, etc; de esta manera es posible observar eventualmente un cambio en el papel que desempeña la literatura en la actividad cultural de una sociedad en transición del Viejo Régimen hacia una sociedad burguesa.

Antes de entrar en el análisis de algunos textos del xvIII y en el tratamiento de la tertulia cabe reflexionar sobre algunas implicaciones epistemológicas que, desde un punto de vista de la historia de la cultura o de la literatura, se deben tener en cuenta.

A la luz de la progresiva y conflictiva secularización de la cultura española, el tipo de sociabilidad que constituye la tertulia se ofrece como el escenario y la forma misma del intento de establecer una nueva manera de representación del saber ${ }^{9}$ y de la reflexión ética y moral ${ }^{10}$. Esta es una carac-

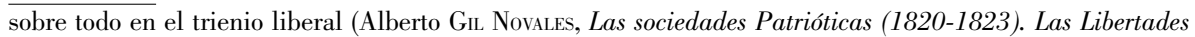
de expresión y de reunión en el origen de los partidos políticos, 2 vols., Madrid, Tecnos 1975) pero también a lo largo del siglo xix.

${ }^{8}$ Cfr. N. Marín, Torrepalma y la Academia del Trípode; Tortosa Linde, La Academia del Buen Gusto de Madrid; Egido, «Oralidad y escritura en los certámenes y academias», Carrasco Urgorti, «Notas sobre el Vejamen de Academias», Kenneth Brown, «Aproximación a una teoría del «vejamen» de Academia en castellano y catalán en los siglos xvII y xVIII: de las academias españolas a la Enciclopedia francesa», en: RodRíguez Cuadros, De las Academias a la Enciclopedia, págs. 225-262.

${ }^{9}$ Para subrayar la importancia y lo innovador de este hecho hay que recordar que el éxito del Teatro Crítico Universal de Feijoo como innovador del discurso científico de la época se debe en parte al tono conversacional que define este texto, un tono — a pesar de su estilización por Feijoo- en parte análogo al que encontramos en las tertulias. Esta significación innovadora y catalizadora de la tertulia la vemos claramente al darnos cuenta de que la tertulia es en algunos casos una etapa intermedia antes de la constitución de una academia científica con aprobación real; pensemos en la sevillana Regia Sociedad de Medicina salida de una Tertulia hispalense médico-chimica-anatómica y mathemática, o a la Real Academia Nacional de Medicina sucesora de una Tertulia literaria médica matritense. Lo mismo vale para la Real Academia Española o la Real Academia de la Historian ambas nacidas de diferentes tertulias. En un plan más popular (y más conservador) véase por ejemplo de Pedro M. ${ }^{a}$ de Olive: Las noches de invierno. Biblioteca escogida de historias, 
terística que siempre se ha de tener en cuenta cuando se analicen las formas con las que se representan la tertulia en la literatura o en otros medios artísticos. Al investigar el origen y desarrollo de una nueva forma de interacción y formación de un saber (científico, moral etc.) en la España del XVIII, - un saber que, a su vez, se confirma directamente en un hacer dentro de la sociedad representada por la tertulia-, tenemos que preguntar por los lugares de la comunicación, a saber las Sociedades Económicas de Amigos del País, las academias, el Ateneo, el Liceo (si incluyéramos el xIx), la prensa, el teatro, pero también la censura, la biblioteca, que para Sarmiento constituye una patria simbólica de la República de las letras ${ }^{11}$ : lugares que todos presuponen una forma particular de acción y de autorrepresentación de los individuos ${ }^{12}$. La tertulia es uno de esos lugares simbólicos de comunicación que presenta, además, el interés de constituir un cruce entre las diferentes instituciones y sectores de la sociedad que se dan cita en ella y de señalar por lo tanto el dinamismo de la interacción de los mismos. Una hipótesis sería que la tertulia es un elemento catalizador con respecto a procesos de transformaciones culturales de la sociedad: transformación de una sociedad estamental, de índole aristócrata, hacia una nueva forma de concebir la sociabilidad y cohesión social urbana, desarrollo de un concepto moderno de subjetividad fuera de la normativa religiosa, de un concepto del público, de la relación entre los sexos ${ }^{13}$.

\section{La problemática de la representación}

Un análisis de la tertulia a partir de una perspectiva de la historia cultural, es decir, teniendo en cuenta formas y procedimientos de la representa-

anécdotas, novelas, cuentos, chistes y agudezas, fábulas y ficciones mitológicas, aventuras de hadas y encantadoras, relaciones de viajes, descripciones de países y costumbres singulares y raras maravillas y particularidades admirables de la naturaleza y del arte. Madrid: Espinosa (1796-1997), 5 vol.. [Madrid: Imprenta que fue de Fuentenebro 1937] o el texto de Antonio de Valladares y Sotomayor, Tertulias de invierno en Chinchón: conversaciones crítico-políticas, morales, é instructivas, del año 1815.

${ }^{10}$ Para dar tan sólo algún ejemplo se puede decir que la tertulia se convierte en el lugar de una intensa discusión del concepto de amistad aunque la esperanza de más de un autor en que sea un lugar de la sinceridad se revela utópico (Francisco SÁnchez-Blanco, «La prosa de las tertulias. José Cadalso - Tomás de Iriarte», en: íd., La prosa del Siglo XVIII, Madrid, Ed. Júcar, 1992, págs. 151-164; íd., «Una ética secular: La amistad entre los ilustrados», en: Cuadernos de Estudios del Siglo XVIII, 2 (1992), págs. 97-116).

11 Álvarez Barrientos/Lopez/Urzainqui, La República de las Letras, pág. 13.

${ }^{12}$ Hans Ulrich Gumbrecht, Eine Geschichte der spanischen Literatur, Frankfurt am Main, Suhrkamp, 1990, pág. 552.

${ }^{13}$ Para la problemática del cortejo $c f r$. Carmen MARTín GatTe, Usos amorosos del dieciocho español, Barcelona, Ed. Anagrama, 1987 [1972]. 
ción de hechos culturales, constituye, por más de una razón, una dificultad que es al mismo tiempo un desafío para toda descripción científica. De hecho, la representación y el análisis consecutivo de procesos interactivos dinámicos ${ }^{14}$, entre sujetos o entre el sujeto y la sociedad presentaban ya para la literatura del XVIII toda una gama de posibilidades determinadas por elementos extra e intertextuales. Es esa gama de posibilidades, que seguidamente vamos a desarrollar, una de las razones por la que la tertulia ficcionalmente (re)construida es un lugar tanto de una autorreflexión literaria como de una autorreflexión sobre la relación individuo-sociedad. De esta forma es posible analizar la reacción de diferentes estratos de la sociedad ante procesos de transformación de la misma, procesos que necesariamente tienen su repercusión en modelos comunicativos y en formas de su representación estética. Pensamos, por ejemplo, en la crítica de la tertulia a partir de una perspectiva costumbrista o en su progresiva revalorización en los escritos autobiográficos de muchos de los hombres de letras del siglo XvIII, o en la discusión de su dimensión intercultural $^{15}$.

\footnotetext{
${ }^{14}$ En cuanto a la mezcla de formas orales y escritas de la comunicación en la tertulia y su representación en un texto literario entran en juego procesos de la reproducción del lenguaje oral en lenguaje escrito, la influencia de normas retóricas (que a su vez cambian) así como la dinámica de una circulación interdependiente de dos sistemas de comunicación: en la tertulia circulan textos escritos, en un sentido inverso, y en ellos circula y se fija la tertulia. Esta interrelación hace posible la circulación y propagación de la tertulia también fuera del ámbito de sus participantes ( $c f r$. el papel de la correspondencia) con efectos retroactivos sobre la autoestimación y la cohesión de la tertulia.

${ }^{15}$ Cfr. de Alejandro Moya: El Café. Dialogos imaginados con motivo de las tertulias de los cafés (1792), texto en el que encontramos una tertulia compuesta de procedentes de diferentes naciones y o ya en el XIX un texto como La gaviota de Fernán Caballero donde la autora llega incluso a considerar la forma específica de comunicación que es la tertulia como elemento característico de la nación española: «Recelamos que al leer estos ligeros bosquejos, los que no están iniciados en nuestras peculiaridades, se fatigarán, a la larga, del estilo chancero que predomina en nuestra sociedad. No estamos distantes de convenir en esta censura. Sin embargo, la costumbre lo autoriza; aguza el ingenio, anima el trato y amansa el amor propio. La chanza se recibe como el volante en la raqueta, para lanzarla al contrario, sin hiel al enviarla, sin hostil susceptibilidad al acogerla; lo cual contribuye grandemente a los placeres del trato, y es una señal inequívoca de superioridad moral. Este tono sostenidamente chancero, se reputaría en la severidad y escogimiento del buen tono europeo, de poco fino; sin tener en cuenta que lo fino y no fino del trato, son cosas convencionales. En cuanto a nosotros, nos parece en gran manera preferible al tono de amarga y picante ironía, tan común actualmente en la sociedad extranjera, y de que se sirven muchos, creyendo indicar con ella una gran superioridad, cuando lo que generalmente indica es una gran dosis de necedad, y no poca de insolencia» (La gaviota, Madrid, Castalia, 1979 [Clásicos Castalia 95], págs. 41 sig.). En este pasaje los elementos de un cierto comportamiento comunicativo (su carácter inofensivo de juego, vid. la comparación con el juego de pelota, subrayando el placer de la sociabilidad) sirve para definir un tipo de subjetividad delante del horizonte de una cierta tradición española (el acto comunicativo como base de una segunda «arte de agudeza e ingenio»), para fortificar el amor propio y para consolidar los relaciones intersubjetivas; y se valora este acto comunicativo de una forma moral («superioridad moral») e intercultural. En la sociedad extranjera predominaría el así llamado «buen tono europeo», que por sentirse superior a la forma de relacionar y comunicarse en España en realidad no sería nada más que de la «amarga y picante ironía».
} 


\section{La intertextualidad}

Otro elemento importante es la ya mencionada dimensión intertextual de la tertulia. La relación intertextual más obvia es con el teatro, campo de origen etimológico de la palabra tertulia. Constan algunas analogías más bien estructurales, como por ejemplo la importancia de la máscara (no sólo porque a veces se utilizó en la tertulia un seudónimo), de la puesta en escena, de una cierta indumentaria para la tertulia. Estos signos de una cierta teatralidad de la tertulia se pueden analizar de forma histórica ${ }^{16}$ y relacionar con la génesis del sujeto moderno y su relación con la sociedad. Pensemos también en el hecho de que muchos textos del XVIII sobre la tertulia son sainetes o pequeñas obras de teatro. La relación con la tertulia en estos casos va más allá del mero título de la obra teatral donde aparece a menudo esta noción ${ }^{17}$. En la mayoría de los casos ponen en escena una tertulia que invirtiendo la situación teatral «real» se convierte a su vez en público de una obra de teatro. Pero al invertir y desdoblar de forma ficcional el comportamiento del público teatral, estas obras, consideradas desde otro punto de vista, no son más que la representación de la llamada comedia casera. El juego entre ficción y realidad llega hasta tal punto que, por la ambivalencia o ambigüedad generada, hemos de preguntar cuál de las dos constituye el ámbito ficticio o real. Juego ${ }^{18}$ y juego musical ${ }^{19}$ son elementos suplementarios de una puesta en escena de la tertulia.

${ }^{16} \mathrm{Cfr}$. los análisis hechos para las academias literarias del siglo XVII por Aurora EGIDo, «Oralidad y escritura en los certámenes y academias»; Pasqual Mas i Usó, «Academias Valencianas», en: Rodríguez Cuadros, De las Academias a la Enciclopedia, págs. 173-224 etc. Estos autores hablan del parentesco de la academia ocasional con la fiesta barroca, de una cierta «espectacularidad» de la academia literaria y nos podemos preguntar por una filiación hacia la tertulia del XVIII y XIX.

${ }^{17}$ Citamos algunos ejemplos: La tertulia extravagante, Las tertulias de Madrid, La tertulia discreta, La tertulia de moda, La tertulia del Prado, La tertulia de confianza, La tertulia general, La tertulia descompuesta, La tertulia ignorante y muchos más.

${ }^{18}$ Citamos algunos ejemplos de textos que ven en la tertulia un cuadro para el juego: José Manuel MARTín: Tertulia de la aldea, y miscelanea curiosa de sucesos notables, aventuras divertidas y chistes graciosos, para entretenerse las noches de invierno, y del verano. Madrid: En la oficina de D. Manuel Martín 1782. 2 vols. ; El Remedio de la melancolia: La Floresta del año de 1821, o coleccion de recreaciones jocosas e instructivas. Obra nueva que contiene lo que se ha escrito é inventado mas agradable por autores modernos hasta el año de 1821, en clase de anecdotas, apotegmas, dichos notables, agudezas, aventuras, sentencias, sucesos raros y desconocidos, egemplos memorables, chanzas ligeras, singulares rasgos históricos, juegos de sutileza y baraja, prolemas de aritmética, geometría y fisica, los mas fáciles, agradables é interesantes. Traducidas y recopiladas de diferentes autores franceses y otros. Por Don Agustin Perez Zaragoza Godinez; Mariano de Rementería y Fica: Manual completo de juegos de sociedad, o de tertulia y de prendas. Paris: Garnier 1892 [Madrid 1831]; Librito curioso y entretenido de juegos de manos para divertirse en cualquier tertulia sin causar perjuicio. Madrid, 1850; Francisco Mazon, La Tertulia; colección de pensamientos poéticos, charadas, enigmo-charadas, enigmas, acertijos, logogrifos, rompe cabezas y otros escesos, por varios ingenios montañeses, Santander, Impr. de Salinis y Cimiano, 1876.

${ }^{19}$ Cfr. La Tertulia. Tonadilla a tres. por Pablo Esteve 1765, La Tertulia extravagante. Musica de Sainetes. p. B. de Laserna o La Tertulia realista. Intermedio dramatico. Compuestos de algunos dialogos sueltos y 
Existen otras relaciones intertextuales que, por razones de espacio, no podemos más que mencionar sin entrar a detallar ni explicitarlas. Se puede observar, y lo volveremos a ver hablando del papel de la tertulia para Cadalso, de la importancia del pensamiento mitológico para concebir e imaginarse la tertulia en el XVIII. Ya hemos dado algunos ejemplos. Existen también muchas interferencias con la prensa, no sólo por el hecho de encontrar la palabra «tertulia» en diversos títulos de periódicos y revistas (por ej. El novelero de los estrados y tertulias y Diario universal de las bagatelas de Nifo), sino también porque otros están concebidos como si fueran los miembros de una tertulia quienes intercambian novedades (por ej. El duende especulativo sobre la vida civil, $1761^{20}$ ), o como si fuera un participante en una de ellas quien aporta lo que ha observado (por ej. El Pensador de Clavijo y Fajardo). Esa función de centro de colección y distribución de información, lejos de ser un mero modelo ficticio era en realidad una función importante de la tertulia. En otros casos es la tertulia, real esta vez, el origen de la fundación y publicación de periódicos (por ej. el Semanario Patriótico y la tertulia de Manuel José Quintana ${ }^{21}$. Queda patente, por estos y otros ejemplos, el papel importante de la tertulia para la génesis de un concepto de público, o de espacio público.

Otro elemento constitutivo de toda una red intertextual es la narración o relato de viajes, que hace de la «tertulia» una etapa imprescindible, tanto como lugar de intercambio — de mediación entre lo propio y lo ajeno- como de ámbito en el que se proyecta la visión del mundo exterior.

Y campo importante de intertextualidad es también la narrativa. En muchos textos la tertulia aparece como el lugar de recepción de muchas obras novelescas, frecuentemente muy breves, de manera que se constituye como marco de un desarrollo narrativo ante un público particular: una constelación muy interesante de observar en cuanto a la controvertida cuestión sobre la implantación del género novelístico en España.

\section{La tertulia, ¿un género literario?}

La representación problemática e intertextualmente determinada de la tertulia que acabamos de bosquejar y que muestra la permeabilidad de las fronte-

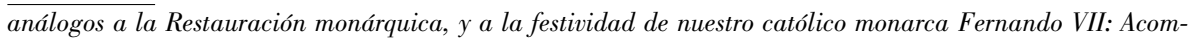
pañada de piezas poéticas al mismo objeto, de baile nacional y de himnos en loas de S.M. Escribialo D.J.M.C. [José Maria de Carnerero] para ser egecutado el día de S. Fernando en el teatro del Principe. Año de 1824.

${ }^{20}$ Cfr. Ana María Freire, Paul J. Guinard «La prensa española del siglo xviII», en: Guillermo Carnero (ed.), Siglo XVIII (1) (Historia de la literatura española, ed. Víctor García de la Concha), Madrid, Espasa Calpe, 1995, págs. 25-39, pág. 32.

${ }^{21}$ cfr. GIL Novales, Las sociedades Patrióticas (1820-1823), pág. 7. 
ras entre ficción-realidad, entre tertulia representada y tertulia como marco de la representación, entre crítica de una parte del público y puesta en escena de un público crítico, implica a nuestro modo de ver algunas consecuencias para el desarrollo de los géneros literarios. Se puede afirmar que, en el caso de algunos pocos textos, la palabra tertulia sirve también para caracterizar un subgénero literario: lo que muestra cuán insuficiente resulta en un momento dado el sistema de los géneros tradicionales para comunicar un cierto saber. Pensamos en textos como, por ejemplo, Tertulia Crytica. Discurso sobre el papel: Systema Politico de la Europa, que en forma de Dialogo, entre un Francès, y un Alemàn saliò al publico en nombre de Monsieur Margnè, publicado en 1734 por Sanchez de Torrijo, o la Tertulia histórica y apologética, o Examen Critico, donde se averigua en Chrisòl de Monumentos antiguos y Escritores de mayor autoridad, lo que contra Fray Geronimo en el Tomo primero de su Theatro Critico Universal. Discurs. I.\$.4.Num.II, por el Doctor Don..., Professor de Ambos Derechos en la Universidad de Zaragoza de Ardanaz y Centellas (s.l., s.a.). Aquí se hace visible un cambio en el sistema de los géneros literarios que halla su expresión en la tertulia como género, como texto literario. Esta función innovadora de la tertulia se puede comparar con la del ensayo, que ya en el xvIII reemplazó formas más antiguas de reflexión y representación del saber.

La tertulia constituye así, no sólo el lugar en la sociedad donde nace un discurso crítico fuera de las formas institucionalizadas en el Viejo Régimen, sino también el núcleo de una nueva sociedad (público), lo que conlleva nuevas formas y funciones de la literatura y una nueva imagen de la posición del escritor como (epi)fenómeno (o anticipación) del cambio sociocultural. Baker, al hablar de la Comedia nueva de Moratín se refiere al café (lugar también de tertulia a finales del XVIII) como del «socially promiscuous model of the market», de un lugar de la «mediation» ${ }^{22}$ en el que la literatura se ve confrontada con nuevos desafíos que ya no tienen nada que ver con los imperativos jerárquicos y tradicionales del Viejo Régimen. Este cambio lo reflejan algunos textos autobiográficos de escritores de principios del siglo XIX, como Mor de Fuentes, para quien la participación en ciertas tertulias es ya una prueba de promoción social ${ }^{23}$.

${ }^{22}$ Edward BaKer, «In Moratín’s Café», en: Hispanic Issues, 1 (1987), págs. 101-123, pág. 103.

${ }^{23}$ Así nos refiere como participó en una tertulia con personajes importantes: «Habia tratado en Santander al ex-Gobernado del consejo, D. Gregorio, de la Cuesta, que tan considerable y tan desgraciado papel hizo despues en la guerra de la independencia; y como pasé placenteramente el verano en Bilbao, disfruté la amena tertulia de nuestro célebre y sabio, aunque un tanto pedantesco, general Mazarredo, á la cual concurría el ex-Ministro instruido y despejado, pero erguido y campanudo, Urquijo» (Bosquejillo de la vida y escritos de Don José Mor de Fuentes. Delineado por él mismo, Barcelona, Impr. de D. Antonio Bergnes, págs. 44 sig.) Otras veces nos dice haber participado en una tertulia con el ministro Cevallo o haber frecuentado en el tiempo de la publicación de su Serafina las tertulias más en boga en Madrid (ibíd., pág. 54). 
Después de estas reflexiones teóricas que circunscriben un campo de investigación que reservamos para un trabajo más amplio, queremos presentar tres ejemplos que desde diferentes perspectivas pueden ilustrar lo dicho sobre la tertulia y su representación literaria. De las muchas perspectivas de análisis desarrolladas hasta aquí tan sólo nos preocuparemos de la cuestión de la conceptualización de los cambios en las relaciones interpersonales e intersubjetivas, es decir, del llamado «trato humano». ¿Qué imagen de la convivencia se trasluce en la representación de la tertulia ante el trasfondo de una progresiva secularización de la sociedad española hacia el final del siglo xvIII? Los ejemplos que tratamos a continuación permitirán ver descripciones diferentes de la tertulia en textos de diverso género: discursivo, dialogal, autobiográfico y narrativo.

\section{El discurso religioso}

Que para la sociedad española del siglo xvIII la tertulia era un fenómeno nuevo y por lo tanto perturbador lo vemos al considerar la reacción, a menudo muy violenta, por parte de círculos eclesiásticos. Esta actitud no coincide siempre con la realidad social donde la tertulia cuenta a menudo con participantes del clero. El anónimo Tratado sobre las tertulias (Barcelona, s.a) se dedica al fenómeno de una forma estrictamente discursiva, siguiendo una argumentación que para su autor es coherente y infalible. El segundo texto, Los vicios de la tertulia de Gabriel Quijano (s.l., 1785) se acerca a la tertulia a través de un diálogo imaginado entre un sacerdote, Don Gil, y una dama, Doña Proba ${ }^{24}$. Las innumerables invectivas en contra de la tertulia no las podemos enumerar aquí por interesante que fuera el análisis exhaustivo de este discurso para una historia de las mentalidades; se trata más bien de detectar las razones de la sorprendente agresividad escondida detrás de esos calificativos y de su puesta en escena en el texto. Nos permitimos, sin embargo, algunos ejemplos. Dice Don Gil: «Esta costumbre moderna es una verdadera, legítima, y natural invención diabólica, que con el especioso titulo de urbanidad y pasatiempo señoril, introduce una infinidad de escándalos, sospechas, y murmuraciones en el Pueblo» (pág. 8). Para él la tertulia es el «camino mas derecho para condenarse, que la moderna costumbre de comunicarse y conversar» (pág. 74). «Señor Don Gil, Vmd. no sabe

\footnotetext{
${ }^{24}$ Aunque aparentemente este diálogo termina con la victoria de la moral cristiana — la dama promete en el futuro no volver a participar en una tertulia—, no obstante deja al lector una impresión ambivalente: la libido dominandi del sacerdote se parece en realidad mucho al cortejo que pretende criticar bajo la forma de la tertulia ( $c f r$. el vocabulario militar del eclesiástico con el que quiere convencer/conquistar a la dama).
} 
hablar sino del Infierno, como si todos fuésemos (sic) Judíos, Turcos, herejes, ò Gentiles: vamos claros, que nuestra tertulia no es ninguna compañía de Asesinos, ò Salteadores de caminos. Don Gil. Aun es peor; pues en los caminos no se asesinan sino los cuerpos; mas en las tertulias y conversaciones son asesinadas las almas» (pág. 95).

Las tertulias aparecen como «lazos del Diablo» (pág. 98). En el transcurso de la argumentación de los dos autores - en esto representativos de muchos otros más - se ve claramente que la tertulia está condenada por constituir la anticipación de un nuevo orden social en el cual la ideología dominante, la ortodoxia, y, sobre todo, su mediación y propagación por la Iglesia estuviera en peligro. El Tratado sobre las Tertulias lo expone ya en su tabla: el segundo capítulo, dedicado a los bienes espirituales que la tertulia supuestamente impediría alcanzar, afirma que éstas ponen en peligro los «principales medios de santificarse, y salvarse» (pág. 63), imposibilitan el camino del individuo hacia la redención y constituyen por tanto una amenaza para la moral cristiana. En segundo lugar, y en relación con esta primera acusación, supondrían un grave riesgo para la vida religiosa pues las tertulias «son asimismo impedimento de grandes bienes, particularmente espirituales: retardan la frecuencia de Sacramentos, son de grande embarazo para la oración, Lección espiritual, Misa, Rosario, y generalmente para todos los Ejercicios de piedad, que es decir, para los principales medios de santificarse, y salvarse» (págs. 62 sig.). Todos esos ejemplos y otros más que no citamos giran alrededor de la palabra divina revelada y predicada por la Iglesia como conformadora de estructuras sociales. La tertulia desde esta perspectiva no sólo perturba el orden espiritual sino también social en la España de la época. Por ejemplo se insiste muchas veces en la práctica religiosa en el interior de la familia. La argumentación se concentra en la organización temporal de la vida individual y colectiva. La participación en una tertulia hace más complicada o incluso imposibilita la participación en la vida religiosa. Es como si la mañana y la noche, como espacios temporales más adecuados para el «recogimiento» (pág. 85) y el diálogo con Dios, estuviesen ya ocupados por ella. El principio del retiro se confronta con el de la dispersión (pág. 129). Ya no queda tiempo para la preparación espiritual, virtud religiosa imprescindible para abrirse al diálogo con Dios:

O Tertulias! que en lugar de actos de fe, confianza, amor, humildad, contricion, y de semejantes, hechos ya como era justo, y muy debido desde la noche antecedente para prepararse à la Sagrada Comunion, haceis que precedan chanzas, bullas, chocorrerias, halgazara, y acaso cortejos, murmuraciones, y otros desordenes, que hagan no poco peligrosa la Comunion, no menos que la Confesion (pág. 84) 
Para el autor del Tratado no puede haber ni compromiso ni modus vivendi que reconcilie dos maneras de concebir la sociedad; prevalece una visión holista, absoluta que no admite el diálogo, la moderación: «De forma, que basta en una alma, ò familia introducir la Oracion, para desterrar enteramente las Tertulias en casa propia, y no asistir en la agena: al contrario basta introducir, ò frequentar las Tertulias, para desterrar la Oracion de qualquiera familia, ò sugeto particular, la experiencia no da lugar à dudarlo» (págs. 91 sig.). No se concibe una alternancia de las diversas actividades:

En efecto: la mañana, ó tarde en el Sermon, y la noche en la Tertulia, que ha de resultar, sino destruir quanto se havia edificado?» (pág. 327). «Es constante, ni se puede dudar, que al paso que las Tertulias irán creciendo, y estendiendose, irá descreciendo, y disminuyendo el exercicio santo de la Oracion, y con ello descaecerá seguramente la devocion, la practica de la virtud, la delicadeza de conciencia con la privacion de otros innumerables bienes (pág. 92)

Todo ello es un diagnóstico de las posibles consecuencias secularizadoras de la sociedad. Se puede observar en estos textos cómo los límites de espacios funcionales de la sociedad se diluyen y vuelven a delimitarse según nuevos criterios y necesidades. Doña Proba da a entender a su interlocutor no estar dispuesta a aceptar, dentro del ámbito privado en el que se sitúa el diálogo entre las dos personas, el tono de predicación con que le dirige la palabra. Justifica esta amonestación con el imperativo de una actitud comunicativa adecuada según el tiempo y el lugar, un argumento no sólo en favor de una nueva economía temporal sino también en contra de la omnipresencia religiosa dentro de la sociedad y, en consecuencia, en favor de una nueva diferenciación funcional de esta última (pág. 2). A su vez, el autor del Tratado teme, hablando de la misa, que ésta sea influida por la tertulia: «Llegados à la Iglesia, allí formarán entre ellos una nueva Tertulia, hablando, y conversando con descaro, $[\ldots]$ cosa en realidad llena de escándalo, que irrita sumamente à Dios» (pág. 102). El carácter subversivo de esta práctica, de esta sustitución, se documenta con el ejemplo de la predicación. Escucharla significa aprender y respetar la ley divina; la compenetración de la misa por ciertos elementos de la tertulia sería señal, siguiendo esta lógica, de desobediencia a la ley divina ${ }^{25}$. El Tratado sobre las tertulias no se limita a condenar el modelo comunicativo y social de la tertulia; su

\footnotetext{
25 «la necesidad de oír la Divina palabra suele ser suma en las almas, asi para entender la ley, como para animarse à observarla; y sin duda que en muchos de los que frequentan Tertulias, puede ser sea extrema. En efecto quantos, y quantas de los que las frequentan no saben tal vez ni lo que es absolutamente necesario para salvarse? [...] Quien à vista de esto no concluirá que los que frequentan Tertulias frequentemente
} 
autor propone más bien, con la conversación antes o después de la comida, una alternativa que tenga en cuenta el impulso humano de conversar. Pero justifica esta propuesta, y esto es lo interesante, no con algunas consideraciones prácticas, sino con un argumento religioso: el ritmo de vida y las reglas monásticas. El Tratado sobre las tertulias acaba muy consecuentemente con un final impresionante, en el que la concepción cristiana de la escatología se opone a la nueva economía temporal de la tertulia que domina siempre nuevos espacios de la sociedad. Ante el tribunal divino el tertuliante debe preguntarse si se ha comportado de forma responsable con el tiempo de su vida terrenal; en opinión del autor, el pasatiempo fugitivo de la tertulia no cumple con esta norma. A partir de la imagen del juicio final, el texto termina llamando a los defensores de la fe a convencer a sus semejantes de sus peligros:

Gritad, clamad, llorad, dad clamores como de aullidos al Cielo, para impedir tan grande mal. [...] Ni ceséis de clamar por mas que no oigan; antes por lo mismo levantad mas la voz como de trompeta, para que entiendan todos del menor hasta el mayor los inconvenientes, los peligros, y fatales consequencias de esas salidas de noche, y diversiones nocturnas con desercion de las familias, para que siquiera se haga la causa de Dios, y no puedan alegar ignorancia en el Divino Tribunal (pág. 329).

Queda patente que este estilo «argumentativo» militante, autoritario y monológico se enfrenta claramente a las normas de urbanidad de la tertulia; lo mismo vale para las muchas citas de textos bíblicos con las que los dos autores quieren prestar autoridad a su argumentación. Cuando Doña Proba señala a Don Gil que, aunque quede victorioso frente a una mujer, su triunfo no estaría asegurado ante los «espíritus que vienen à la conversación» (pág. 71), la única respuesta de éste reside en la amenaza de exorcizar y acallar a estos espíritus libres: «Don Gil. Antes bien, si encontrase alguno de esos espiritus que Vmd. dice, apretaria con los exorcismos, y lo haría volverse un espiritu mudo, obligandole à no infestar tanto las casas agenas, con especialidad los gabinetes de las mugeres» (pág. 71). En este intento de silenciar e impedir un verdadero diálogo, en la conducta social muy ambivalente del sacerdote Don Gil frente a la mujer o en el furor clasificador con que el autor del Tratado intenta ordenar y, por consigiente, superar el fenómeno de la tertulia, observamos algunas estra-

\footnotetext{
tienen la mayor necesidad de oir la Divina palabra, ya por instruirse, ya para desengañarse, y ya por animarse à observar la ley, y salvarse? Sin embargo, ò malignidad de las Tertulias! ellas mismas que ocasionan à sus concurrentes la mayor necesidad de oír à menudo la palabra de Dios, se lo impiden, ò dificultan por tres partes» (págs. 120 sig.)
} 
tegias de la época para compensar un fenómeno cuyo carácter subversivo o, por lo menos, sintomático de un cambio fundamental de la sociedad, podemos leer entre las líneas de los textos que acabamos de analizar.

\section{El discurso ilustrado}

En segundo lugar nos ocuparemos de Jovellanos, un autor para el que la tertulia no constituye una amenaza sino, esta sería por lo menos nuestra tesis, centro autobiográfico y núcleo de un nuevo orden social secular. Sus anotaciones del Diario son elocuentes ${ }^{26}$ :

A la tertulia; poca gente; conversación con el cleriguito Barroeta [...] sobre gramática castellana y su importancia. A casa, cena ligerísima (pág. 231); Tertulia; lectura del Ensayo de Filosofía moral, de Maupertuis; al fin en la Historia del Nuevo Mundo (pág. 265); tertulia muy concurrida y bien cebada la curiosidad con las noticias de correo (pág. 274); Paseo. Tarde al dibujo. A los pintores; al ensayo. En casa el visitador, de tertulia. Lectura en Gil Blas (pág. 284): A la tertulia en casa de la Comisaría, viuda de Mollinedo; gran concurrencia; mesas de bisbís; tres de rocambor y mucha gente sobrante para conversación (pág. 356). Tertulia al ordinario (pág. 397); Tertulia escasa (pág. 397).

Si incluimos sinónimos los ejemplos proliferan todavía más:

Primer día de chimenea. Se reúne la antigua tertulia. Lectura en Gil Blas (pág. 288); Chimenea y chaquete con Llanos. Tertulia al ordinario (pág. 397) Tarde al Instituto. Paseo en casa; chimenea; lectura en Young y en Cook. Ayer y hoy partida de mediator (pág. 322); Discurso. Tarde al Instituto: faltaron algunos al ejercicio poético. Paseo. Chimenea. Correo (págs. 322 sig.). Paseo; lluvia blanda. Chimenea; conversación con Caveda, en la mayor parte sobre artes y letras. Cook (pág. 325). Al Seminario, a ver los niños de Valdés: [...]. Cena. Después, conversación con los maestros y con un poeta improvisante; se habló mucho de humanidades y de métodos de estudios (pág. 371).

El estilo breve, casi de telegrama, tan típico de su diario, que de forma lacónica (algunos dirían frenética) se limita a recordar etapas esenciales y a menudo recurrentes en la vida del autor, más bien en la forma y el ritmo de la vida de

${ }^{26}$ Gaspar Melchor Jovellanos, Diario, ed. José Miguel Caso González, Barcelona, Planeta, 1992. 
un intelectual y político de esta época que en su contenido, sitúa la tertulia a un mismo nivel que otras ocupaciones intelectuales tan importantes como escribir, leer y enseñar. El carácter ritual de la tertulia en la compañía de Jovellanos está por lo menos tan marcado como el de la actividad religiosa; aún durante días festivos de gran importancia como la Semana Santa encontramos a Jovellanos cada día en su «tertulia acostumbrada» (pág. 66).

El Corpus; procesión que vimos junto a San Isidro; fuimos a casa del canónigo don Pedro Pizarro, donde almorzaban los Villadangos y la sobrina Tadea Tineo. Por la tarde paseo, y a la noche tertulia. Tiempo de asamblea, y muchos oficiales de milicias en ella. Viernes, 8. Primer tratado para la elección; sin novedad; por la tarde ejercicio de milicias; por la noche tertulia (págs. 65 sig.).

También el Viernes Santo apunta: «Por la noche la tertulia acostumbrada» (pág. 66). Donde los autores religiosos de que tratamos más arriba ven la fuente de toda dispersión, la tertulia, en el diario de Jovellanos, constituye por el contrario el foco de una vida llena de vicisitudes. La interferencia de procesos de interacción en la tertulia con los procesos sociales en general, como parece deducirse de las opiniones de Jovellanos, puede ilustrarse bien con un ejemplo concreto sacado de su diario, a saber: los días y semanas anteriores y posteriores de la apertura de Real Instituto Asturiano de Náutica y Mineralogía fundado por él el 7 de enero del año 1794. El cuadro de la tertulia — se habla en el diario de conversaciones, de juego, de música- define un espacio social, cuya realización en un plan nacional es el objetivo del ilustrado Jovellanos. En este sentido la tertulia es una prefiguración de una sociedad centrada en la comunicación y la educación, como la veremos celebrada en los días siguientes en las alocuciones y en el aparato festivo con motivo de la apertura del Real Instituto. Muchas de las posiciones que se exponen allí han sido antes objeto de discusión en las tertulias y también la fiesta después del propio acto de apertura y el «refresco» con baile para más de 300 personas (pág. 156) no son nada más que la extensión a la sociedad en general de la organización de las tertulias en las cuales Jovellanos participó u organizó. Pero hay más: la forma de vida social de la tertulia — una vida centrada en la comunicación, el intercambio, en una intersubjetividad informal (lo que no impide un cierto orden y estructura) que incluye también otros pasatiempos y actividades (música, juego etc.) es un elemento constitutivo de la visión educativa de Jovellanos. Una semana después de la apertura del Instituto confía a su diario los elementos básicos de sus primeras clases, su introducción a la gramática y al estudio de los idiomas, para él la base de todos los estudios posteriores: el hombre sería la criatura 
con el «don de la palabra, esto es, la facultad de hablar» (pág. 158). Al día siguiente explica a sus 38 alumnos este pensamiento y acentúa su significación para la sociedad:

Sólo el hombre es capaz de hablar, y en este privilegio ha recibido del Creador dos grandes ventajas. Primera: la de comunicar a sus semejantes sus más íntimos sentimientos. Segunda: la de percibir los más íntimos pensamientos de sus semejantes. De entrambas ha resultado la perfección de la razón humana, la cual no puede extender sus ideas, ni comparar las ni perfeccionarlas sino por medio de la palabra o el discurso (pág. 159).

Jovellanos representa aquí la relación comunicativa e intersubjetiva como base del autorreconocimiento y del reconocimiento ajeno, de la integración social y de la perfectibilidad de la razón humana. Estas concepciones hallan su ejemplo en las tertulias que visita Jovellanos como al revés es la experiencia de la tertulia que llega a ser la fuente de tales concepciones. En su diario enumera algunas obras teóricas que le ayudaron en la preparación de sus clases. No obstante estos medios, hace constar: «pero me falta gente con quien hablar para desenvolver mis propias ideas. Espero el Condillac de Oviedo» (pág. 157). Si no lo recibiera, por lo menos no falta gente para discutir e intercambiar ideas. Refiriéndose a la misma noche del 12 de enero dice: «convite en casa de don José Sala, a la que no vamos. Caveda y Montés vienen; conversación con el primero sobre antigüedades. Me ofrece copia de sus inscripciones y de sus descubrimientos. Vi los dibujos de la iglesia de Baños y los borrones de Santa Cristina. Partidas» (pág. 157). Con el mismo Caveda ya había hablado Jovellanos la noche anterior. El 11 de enero escribe: «Por la noche mucha concurrencia. Conversación con Caveda sobre la obra de monsieur de Saint-Pierre y sobre Las épocas de la naturaleza, del conde de Buffon. Entra [Manuel de la] Isla en ella y conoce la última obra. Dos partidas de mediator» (pág. 157). Nuestro análisis de las anotaciones del diario de Jovellanos, en un momento muy crucial para su visión de una vida social futura, se justifica y se generaliza al tener en cuenta otros pasajes donde se tematizan la tertulia u otras formas de comportamiento comunicativo. Queda patente que Jovellanos considera la tertulia como la institución de una educación (social): al visitar, por ejemplo, el progresista Seminario vascongado en Vergara insiste en la importancia de la tertulia que reúne todas las noches a los estudiantes para su programa escolar: «A los diez y ocho años pasan los seminaristas a la clase de académicos; salen por la noche; concurren los días festivos a las tertulias, donde bailan hasta las nueve, que es la hora de cena.». Explícitamente describe a continuación una de esas 
reuniones donde, después de una representación musical, se habla sobre problemas de la agricultura.

Aquí están ahora don José Mon, don Ramón de Eulate y tres Ramírez-Tobía, de Palencia. El joven más sobresaliente es Gomucio, americano y destinado a la Marina. Asistimos al concierto que se tiene todos los días festivos, de cuatro a cinco en el verano, y de siete a ocho en el invierno. Se tocaron unas sonatas de Pleyel; hay un buen fagot; tocaban seis seminaristas con los maestros; por la tarde fueron a divertirse al juego de pelota. Se habló mucho de agricultura. [Sigue la citación de algunos nombres y de su opinión] [...] Concurrencia por la noche en casa de Gaitán de Ayala, después de haber bebido, convidados, en la de Barroeta [...]. Deseé conocer a [Joaquín José de] Landázur [y Romarate], historiador de Vitoria, y hombre, según dicen, de grande instrucción en las antigüedades de este país; no concurrió, como esperaba, a la tertulia. Despedida; cena; Peñalba piensa partir a Bilbao, huyendo de las viruelas. Orden para salir mañana a las cuatro; está aquí el caballo, aunque todavía cojo (pág. 36) ${ }^{27}$.

Un expresivo, aunque indirecto dato en favor del poder emancipador de la tertulia nos lo da un párrafo de su diario donde confronta la decisión del censor de no permitir la compra de libros censurados para la biblioteca del instituto con la descripción de una tertulia marcada por una atmósfera llena de vida y alegría:

Y ¿se hará sistema de perpetuar nuestra ignorancia? Este monumento de barbarie debe quedar unido al diario. ¿Qué dirá de él la generación que nos aguarda, y que, a pesar del despotismo y la ignorancia que la oprimen, será más ilustrada, más libre y feliz que la presente? ¿Qué barreras podrán cerrar las avenidas de la luz y la ilustración? Tertulia entretenida; lectura en la Memoria de Guipúzcoa (pág. 277).

${ }^{27}$ El papel de la tertulia en el diario se debe, después de lo dicho, vincular con los esfuerzos de los que habla en su Memoria para el arreglo de la policía de los espectáculos y diversiones públicas, es decir el desarrollo de una cultura de conversación burguesa como núcleo de un nuevo tipo de sociedad. En este sentido aboga en favor del establecimiento de una pública «casa de conversación». Cfr. también un pasaje de su diario donde relata la visita de algunos de sus amigos: «de sobremesa les propuse la idea de que nos juntásemos a conversación los jueves, de siete a nueve de la noche, para tener algunas conferencias literarias, algo les dije acerca de la idea que yo tengo de mucho tiempo, de formar una Academia [...].pero les indiqué que, por ahora, nuestra asociación no debía tener ningún objeto determinado, hasta tanto que nuestras conferencias fuesen cayendo en él y arreglándole. Aceptaron y aplaudieron la proposición» (págs. 401 sig.). 
Con esta nota Jovellanos deja constancia de la barbarie del censor; pero al mismo tiempo estima también la estrecha relación de la tertulia con el programa de la Ilustración.

Por otra parte, leído su diario a la luz del principio expresado por él mismo acerca del privilegio de la palabra conferido por Dios — «comunicar a sus semejantes sus más íntimos sentimientos. Segundo: la de percibir los más íntimos pensamientos de sus semejantes»— se reconoce claramente que la tertulia es el escenario ideal para ese encuentro.

En uno de los pocos pasajes de su diario donde Jovellanos no refiere sino que reproduce un diálogo entre dos personas, al que por consiguiente parece atribuir una cierta importancia o carga emocional, tocamos la base afectiva de su visión social. El 18 de junio conversa en una tertulia con Ramona Villadangos:

A la tertulia a casa de Diguja; larga conversación con la Ramona [Villadangos]: me confirma en la idea que siempre tuve de su buen talento y buenos principios; poco satisfecha de la conducta de sus pretendientes: menos de la de P[epe] M[aría] T[ineo]; sentida de los chismes e incidentes que alejaron a J[oaquín] M[aría] V[elarde]; se dice conforme con su suerte; poco inclinada a un establecimiento; alejada de él por su carácter; no hay remedio: es preciso abrazarle; alabo su desinterés y me duele mucho que no halle una suerte digna de su mérito (pág. 261).

Algunas semanas después, el 29 de junio la vuelve a encontrar:

A la tertulia; diálogo con $\mathrm{R}$ [amona Villadangos]: «¿Conque mañana se va usted?... Demasiado cierto es. ¿Puedo servir a usted en algo?... Pero usted no tiene ya intereses en Asturias, ni aún tendré ese gusto... Pues yo siento también que usted se vaya... y no sé por qué. A fe que ahora me es más sensible mi partida.» Antes que la converación se empeñase: «Vamos a jugar», dijo, y se levantó. Creo conocer su carácter y cuánto vale aquella sencilla expresión, proferida con tanta nobleza como ternura; pero distamos mucho en años y propósitos. Despedida de todos (págs. 262 sig.).

Aunque la tertulia se ofrece claramente como lugar de encuentro entre los sexos y como intercambio entre conversación y juego, advertimos también lo frágil y precario de una visión social basada en una mezcla de sentimientos a menudo - lo dice el mismo texto- inefables e impícitos. De todos modos, estamos lejos de la visión apocalíptica de la tertulia desarrollada por los críticos clericales. Otro ejemplo de este equilibrio comunicativo frágil pero fascinante es la descripción de una tertulia en su propia casa donde algunas personas se han reu- 
nido después de un convite con música: «iQué bulla! ¡Qué inocente alegría! Quiero poner aquí los que hoy formamos esta familia». Sigue una enumeración de las trece personas de la tertulia con pequeños retratos de cada uno. Y al final de este dibujo se pregunta: «Fuera muy curioso explicar las combinaciones de afición que tanta juventud alegre hace entre sí, pero no hay tiempo a ello; algo va en la carta a Ponte. Vamos a dormir» (pág. 311). Es como si el siempre rápido Jovellanos, tan preocupado por reformar e ilustrar a la sociedad española, no se hbiera tomado el tiempo necesario para reflesionar sobre el fundamento afectivo de toda reforma social.

\section{El discurso liberal}

José Cadalso, para mencionar un último ejemplo, ve en la tertulia un elemento característico de la cultura española y a ello dedica en las Cartas Marruecas algunas cartas (la XI, XXXIII y LVI). Al principio parece dominar un juicio positivo sobre la tertulia, que sitúa al otro polo del antiguo ceremonial que ha contribuido a repartir por Europa una imagen muy ambivalente de la vida social española: «Todo esto sin duda es muy bueno, porque contribuye a hacer al hombre cada día más sociable. El continuo trato y franqueza descubre mutuamente los corazones de los unos a los otros; hace que se comuniquen las especies y se unan las voluntades» (pág. 125) ${ }^{28}$. Esta frase de Gazel también hubiera podido ser escrita por Jovellanos. En un paseo común, Gazel comenta la actitud de su amigo Nuño: «Por esta urbanidad que es casi religión en Nuño» (pág. 180). Aquí parece que estamos definitivamente en los antípodas de la condenación religiosa de la tertulia que vimos al principio; es, por el contrario, la cuestión del trato civil la que parece adquirir carácter religioso. La tertulia en las Cartas Marruecas es, sin embargo, más que un mero objeto de una ojeada costumbrista, un medio que permite a Gazel conocer los elementos específicos de la realidad española ${ }^{29}$. Es obvio además el carácter cosmopolita de las diferentes tertulias que describe en las Cartas Marruecas, por mucho que se acentúen diferencias nacionales. Un modelo de Cadalso fueron las tertulias de la Fonda de San Sebastián en las que él mismo participó. La tertulia sirve aquí no sólo como paradigma de una visión social sino también de un orden internacional: Gazel se queja de las «controversias en las conversaciones familiares» (pág. 221) y las compara con las controversias en la «conversación de las naciones». No obstante esos jui-

\footnotetext{
${ }^{28}$ José Cadalso, Cartas Marruecas, Madrid, Cátedra, 1987.

${ }^{29}$ «Ayer me hallé en una concurrencia en que se hablaba de España» (pág. 259).
} 
cios positivos, el amigo de Gazel, Nuño, cuyas relaciones autobiográficas con Cadalso son conocidas, tiene una apreciación ambivalente de la tertulia: él, de quién se dice al principio que vive lejos del mundo y aprisionado en sí mismo (pág. 83), sin embargo - y Nuño se da cuenta de esa paradoja — pasa la mayor parte de su tiempo en tertulias ${ }^{30}$. «Todas las cosas son buenas por un lado y malas por otro, como las medallas que tienen derecho y revés. Esta libertad en el trato, que tanto te hechiza, es como la rosa que tiene las espinas muy cerca del capullo» (pág. 125). Sigue una larga lista de argumentos en contra de la tertulia que completamos con otros elementos del texto cadalsiano: la tertulia impide el aislamiento necesario para la reflexión, está dominada por una estereotípica conversación, el trato en ellas es una de las razones de la corrupción del idioma (vid. su proyecto lexicográfico que casi se puede considerar como el paralelo lingüístico del descubrimiento de España por Gazel), y hay que reparar en el tratamiento, a veces muy irrespetuoso, de la mujer en las tertulias. El mismo Gazel se ve enfrentado en ellas con algunas experiencias negativas: sintiéndose víctima de un «tirano de la conversación», debe reconocer no disponer del «beneficio del habla, que yo pensé disfrutar por derecho de naturaleza hasta que la experiencia me enseñó que no había tal libertad. Así como al acabarse la tempestad vuelven los pajaritos al canto que le interrumpieron los truenos, así nos volvimos a hablar los unos a los otros» (págs. 119 sig.), como también que el derecho a la libertad de expresión no existe en ningún nivel de comunicación. Estas aserciones suscitan una leve duda en cuanto al intento del pretendido editor de las Cartas Marruecas que introduce en encuadre ficcional un concepto regulador ya tópico para el discurso de la Ilustración, el de una voz de la naturaleza objetivadora, si bien reconoce que a veces no se llega a entender en la confusión de las voces del trato cotidiano de los hombres: «La naturaleza es la única que pueda ser juez; pero su voz, ¿¿dónde suena? Tampoco lo sé. Es demasiada la confusión de otras voces para que se oiga la de la común madre en muchos asuntos de los que se presentan en el trato diario de los hombres» (pág. 79). En el epílogo, en la «Protesta literaria del editor», ya no escuchamos esta voz de la naturaleza, de la cual el autor esperaba que fuese capaz de superar las diferencias entre las naciones, sino la cacofonía de una tertulia, en la que se critican las Cartas Marruecas que acabamos de leer aprovechándose justamente del argumento de las diferencias nacionales:

\footnotetext{
${ }^{30}$ En una carta a Gazel escribe: «Yo continúo haciendo la vida que sabes y visitando la tertulia que conoces». En este sentido no podemos menos de mencionar la parábola discutida entre Nuño y Gazel a saber si la vida retirada en el campo es compatible con el papel de «buen ciudadano» que es para Nuño la condición del hombre de bien (pág. 250-256).
} 
Has de saber que nos vamos a juntar todos en plena asamblea, y prohibir a nosotros mismos, a nuestros hijos, mujeres y criados, tan odiosa lectura; y aun si así logras que alguno te lea, también lograremos darte otras pesadumbres. Nos dividiremos en varias tropas; cada una te atacará por distinta parte: unos dirán que eres malísimo cristiano en suponer que un moro como Ben-Beley dé tan buenos consejos a su discípulo; otros gritarán que eres más bárbaro que todos los africanos en que nuestro siglo no es tan feliz como decimos nosotros, como si no bastara que nosotros lo dijéramos (pág. 305).

Es una visión escéptica de la tertulia. Sin embargo, el mero hecho de poner en escena esta pluralidad de posiciones dentro de su texto y de utilizar para estos fines el medio de la tertulia, lo tenemos que tener en cuenta. Puesta en escena no solamente dentro de la ficción del viaje de Gazel, es también en el encuadre ficcional donde sustituye a la «voz de la naturaleza» como norma estética y ética. Es esto, a mi modo de ver, desde un punto de vista formal, la causa de la «polifonía espiritual» con la que se ha querido caracterizar la dimensión antológica de las Cartas Marruecas. Hasta se puede pretender que la correspondencia ficticia entre las diferentes protagonistas de las Cartas Marruecas se parezca más a una tertulia que a un diálogo tradicional de una novela epistolar.

Un análisis de la correspondencia privada de Cadalso subraya esta lectura. Los saludos a algunos amigos y a su tertulia respectiva, a la academia común, la circulación por cartas y la discusión de textos, el intercambio de novedades etc. llevan a la constitución de una tertulia virtual ${ }^{31}$. En los escritos autobio-

${ }^{31}$ José Cadalso, Escritos autobiográficos y epistolarios (ed. Nigel Glendinning), London, Tamesis 1979. A Nicolás Fernández de Moratín escribe: «Los sonetos se leerán en la academia de Meléndez y su compañero que juntos me hacen tertulia dos horas todas las noches, leyendo nuestras obras u las ajenas, y sujetándose cada uno de los tres a la rigurosa crítica de los otros dos. Dentro de poco tendrá Vmd un cuadernillo de poesías de Meléndez; entre otras hay una elegía a la muerte de mi Filis, imitada de la de Vmd a la de la reina, que le ha de gustar a Vmd no sólo por verse hecho modelo, sino por el mérito esencial de la imitación» (pág. 85). En septiembre del mismo año escribe a un amigo salmantino: «Cumpla Vmd por mí con las personas que me han estimado en esa ciudad, asegurándoles que quedaré eternamente agradecido a las distinciones que me hicieron, singularmente Castellanos, Galiano, Ruano (a quienes escribo hoy), Rico, su tertulia, Armenteros, Bazán, Mesía, y a toda la matrícula de estudiantes, y con particularidad a mis vizcaínos» (pág. 90). A José de Iglesias le recomienda en una carta saludar a Francisco Rico «como también a sus hijos, familia y tertulia» (pág. 90) y le ruega así que a sus amigos: «Envíenme Vmds y los suyos cuanto compongan. La conversación de Vmds. disipará sin duda el tedio que inspira este lugar. A falta de sus palabras, sentiré el mismo alivio con sus escritos, y así, manos a la obra» (pág. 90). Notamos que utiliza aquí la palabra que designa un hecho de comunicación oral, la conversación, para referirse a unos escritos. En marzo del año 1775 saluda a través de José de Iglesias a Rico: «En casa de Rico también ha de dar Vmd memorias mías; entre sus tertulianos tengo amigos de mi aprecio, como Armenteros y Ortiz. [...] En fin, no hay persona en Salamanca que me sea indiferente, así de la universidad como de la ciudad, con que a todos puede Vmd asegurar y repetir mi inútil pero cordial y fino afecto, y de aquí inferirá Vmd en vista de nuestra particular amistad estrechísima, cuánto soy y seré siempre de Vmd Dalmiro» (pág. 101). Le tranquiliza saber que 
gráficos se puede observar, además, el intento cadalsiano de preguntar por la actualidad de algunos conceptos e imágenes tradicionales de una vida en común y de su importancia para la propia subjetividad de un lado y para el papel social del escritor del otro. Domina el escepticismo, la melancolía que marca también la obra de ficción. Cadalso juega, por ejemplo en sus cartas, con la oposición tradicional entre corte y aldea enfrentando a la vida social de la corte la visión arcaica donde «se juntan en mi casa mil pastores,/ y tratan varias cosas y aun amores./ Después de esta asamblea,/ en que ni la virtud ni honor se ofende,/ y el alma se recrea/ y por el campo de placer se extiende,/ cada uno se recoge a su cabaña/ con paz que entre los grandes es extraña» (pág. 59). Pero en vez de contrastar, como hace sistemáticamente en todo el poema, elementos de las dos formas de vida para criticar la vida de la corte, la imagen de la vida social y comunicativa arcádica es descrita más bien como una emulación y purificación de la de la corte, cuando describe por ejemplo la conversación de las aves ${ }^{32}$ con palabras procedentes de un manual cortesano: «no hay tan finos amantes en la corte» (pág. 214), el toro se acerca a la hembra «como el galán más tierno y derretido» (pág. 222); el rey de los pastores se nos presenta como «fino y constante, discreto y sobre todo moderado» (pág. 63). En otro texto de 1775 refiere un sueño donde delinea un espacio utópico:

Cuando reflexiono sobre estas cosas me hago dos composiciones de lugar: la una de mí mismo, habiendo hecho lo que llaman fortuna, colocado a los cincuenta años en la corte con otros amigos de los que así se llaman en ella. Dilato un poco mi imaginación y descubro un campo lleno de abrojos que cultivan en compañía de otros labradores envidiosos, que se arrancan unos a otros con ansia el infeliz fruto de sus trabajos. La otra es la de verme a dicha edad o mucho antes en una aldea saludable y tranquila, con buenos libros y un criado o dos fieles, en la vecindad de los amigos verdaderos, a quienes visitaré en su casa o recibiré en la mía: siempre alegres, sociables, comunicándonos todas las especies que nos ocurran o bien de invención propia, o bien del trato con los muertos; creciendo en edad, ¡qué viejos seremos tan amables y tan buenos! Esta idea me encanta, y el deseo

\footnotetext{
$\overline{\operatorname{los} \text { amigos se }}$ preocupan de su suerte: «61. A José Iglesias, escrita desde Montijo poco después de la anterior. El susto con que Vmd y los otros Académicos están con motivo de mi intento de ir a la guerra, en caso de que ésta se encienda, me prueba lo mucho que me estiman, a lo que correspondo de lo íntimo de mi corazón» (pág. 112) y alude por último al trabajo común: «Me han encantado las noticias que Vmd me da de los progresos hechos por nuestros académicos, y de haber aprobado mi proyecto de publicar un Parnaso Español de poetas hoy vivos» (pág. 113).

${ }^{32}$ De cierto modo se trata de la «voz de la naturaleza» de la que ya hablaba Gazel diciendo «[a]sí como al acabarse la tempestad vuelven los pajaritos al canto que le interrumpieron los truenos, así nos volvimos a hablar los unos a los otros» (Cadalso, Cartas Marruecas, págs. 119 sig.) y aludiendo al comportamiento de algunos tertulianos.
} 
de que se verifique me hace llevar con brío los sinsabores que aún me ofrece la carrera, el mundo que desprecio, y la corte que aborrezco. Todo esto podría llamarse pedantería si lo escribiese un hombre artificioso, pero escrito por mí, que tengo el gusto de haberme adquirido la fama de hombre sincero, no puede mirarse sino como unas reflexiones naturales que salen de una alma colocada fuera de su centro y que lo apetece (pág. 100).

Aquí también dibuja este lugar según el modelo de tertulia que podemos ver descrito en sus cartas y en sus textos ficticios.

Hallamos en su correspondencia un juego melancólico con algunos tópicos de la vida en común en un más allá como el Parnaso ${ }^{33}$, con una notable recurrencia de la imagen de la barca de Aqueronte y su tripulación ${ }^{34}$ y los Campos Elíseos. En su himno a la poesía de Meléndez Valdés llama como testigo al coro de las musas, y aparece en los Campos Elíseos el grupo de los envidiosos que no pueden hacer más que aplaudir a la primacía poética de Meléndez:

Aun cuando dura Parca/ mayores plazos a mi vida niegue,/ y en la fúnebra barca/por la Estigia navegue/ y a las delicias del Eliseo llegue;/ Oiré cuando Catulo/ a la sombra de un mirto recostado,/ con Propercio y Tibulo,/ lea maravillado/ los versos que tu musa te ha dictado;/ cuando acudan ansiosos/ Laso y Villegas al sonoro acento,/ repitiendo envidiosos:/ ¿Qué celestial portento!/ ¿A quién ha dado Apolo tanto aliento?/ Yo, que seré testigo/ de tu fortuna, que tendré por mía,/ diré: yo fui su amigo/ y por tal me tenía,/ gozando yo su amable compañía (pág. 87) ${ }^{35}$.

\footnotetext{
${ }^{33}$ En una carta a Tomás de Iriarte de mayo de 1773 acompaña de forma imaginaria su corresponsal en el más allá en búsqueda de informaciones sobre el tío de éste, Juan de Iriarte. En el camino encuentran algunos grupos de personas que diferencia Cadalso de los «menageries de por acá» (pág. 70). En esta fantasmagoría utiliza también la imagen del (o por lo menos una imagen parecida al) parnaso: «y después de todos estos despueses, volviendo sobre la derecha, se hallaría Vmd en un campo como así me lo quiero, donde encontraría la compañía mas honrada del mundo, de gente sabia, quieta y filósofa. Allí estaría con Séneca, con Marcial, con Cervantes, con Garcilaso, con León y otros sabios españoles el venerable Iriarte, que saldría al preguntar Vmd a aquellos insignes hombres y a su conductora».

${ }^{34}$ De forma lúdica amenaza a su superior con una especie de resurrección de los muertos según cuenta en una carta a Manuel López Hidalgo del mes de diciembre de 1772: «Que para vengar este agravio, si le alcanzo en días, volveré des los Campos Elíseos con Aqueronte; y en su barca, traeré a Sísifo, a Tántalo, a los Titanes, Al Briareo, a los Centauros, a las Scylas, a la Quimera, a las Harpías, Gorgonas, Lapythas, Ixión, Eumenides, y toda la comparsa infernal, con aquello de las hachas, culebras, víboras, sierpes, Cerbero, por adelante, hasta su alcoba; y armará toda esta cuadrilla tal estrépito, estruendo, rumor, bulla, ruidoo, gritería, alaridos, gemidos, silbidos, barahunda, confusión, horror, tempestad, tormento, alborto, terremoto, que no podrá menos de despertarse nuestro buen Jefe» (págs. 66 sig.).

${ }^{35}$ Imágenes cuya precaridad ilusoria se nota más que todo frente a la representación de la comunidad de los muertos - reales esta vez. En una Epístola a Juan Meléndez Valdés y José Iglesias, Epístola a Batilo y Arcadio sobre el rumor de guerra con Portugal o de nueva expedición contra Argel, dice Cadalso: «cadáveres
} 
Juego, pues, que expresa graves dudas acerca de la realización de su ideal, imágenes que probablemente aparezcan, ya en el momento de pintarlas, anticuadas y obsoletas, o como sospechó el mismo Cadalso: «Todo esto podría llamarse pedantería si lo escribiese un hombre artificioso, pero escrito por mí, que tengo el gusto de haberme adquirido la fama de hombre sincero, no puede mirarse sino como unas reflexiones naturales que salen de una alma colocada fuera de su centro y que lo apetece» (pág. 100). Cadalso es consciente del carácter retórico de los imágenes que emplea y que solamente cree poder autentificar por su reputación de seriedad adquirida dentro de la sociedad. Esto le lleva a una aporía, porque es solamente la dialéctica de los imágenes que tiene de sí y que de él tiene la sociedad (y ya no la naturaleza) lo que justifica su intento de imaginar un contra-proyecto a esta sociedad. La ambivalencia de este intento utópico nos da una vista libre sobre esta «alma colocada fuera de su centro», un alma que ha perdido su centro espiritual y que ya no puede encontrar su salud fuera de la sociedad representada por la tertulia.

El miedo de recaer en el caos de la torre de Babel en el que ya no se entiende la voz divina, la esperanza de Jovellanos en la fuerza ordenadora de una razón que se articule en el diálogo humano, y finalmente el escepticismo y la nostalgia cadalsiana a la vista de las posibles pérdidas del habla en el espacio de la sociedad liberal y que intenta compensar con una estructura estética específica encuentran en su heterogeneidad su denominador común en el papel central de la tertulia como medio de la observación y de la auto-observación de una sociedad en cambio.

y cuerpos desmembrados / que juntos forman pálidos montones, / saliendo de ellos lastimeras voces, / de moribundos últimos alientos» (pág. 124). 